\title{
Evitemos la degradación progresiva de nuestro idioma
}

E

el número de diciembre de 2006 de la revista Archivos Españoles de Urología se ha publicado un excelente artículo titulado "Papel actual del antígeno prostático específico y otros marcadores en el diagnóstico del cáncer de próstata" sobre el que deseaba hacer un comentario.

No tengo nada que objetar a su calidad científica pero creo que es necesario corregir el uso del termino "PSA complejado" como sinónimo de los términos anglosajones "complex PSA" o "complexed $P S A^{\prime \prime}$ que en la literatura anglosajona utilizan indistintamente como sinónimos.

Si la traducción literal del termino ingles "complex" es "complejo" deberíamos usar dicho término como traducción de ambos téminos y no inventarnos un neologismo del tipo de "complejado" para traducir la palabra "complexed"

Simple y llanamente al palabra "complejado" no figura en el diccionario de la Real Academia de la Lengua Española. Su uso es un tipo de barbarismo conocido como extranjerismo y consiste en el uso de una expresión lingǘstica tomada de un idioma extranjero y usada en la lengua propia para suplir alguna necesidad de denominación que esa lengua no ha cubierto todavía.

En todo caso, la lengua castellana da muchas opciones como sinónimos del término "complejo" entre las que figuran "complicado, conjunto, intrincado, múltiple, reunido, sumado, variado y combinado". En mi opinión es esta última palabra la que mas exactamente corresponde al término ingles "complexed" y creo que es la que debería utilizarse para su traducción. De no ser así debería describirse de forma integra, es decir como "PSA unido a proteínas"

El uso del barbarismo "complejado" se esta extendiendo de forma inaceptable en diversos campos científicos y si tecleamos esa palabra en un buscador de internet ya salen cientos de páginas con ese término (505 en el momento de realizar esta carta). Ejemplos de frases que hemos extraído de esas páginas web son: "...complejada con un ligando", "....complejada con Fe++" y en todas ellas es fácilmente substituible el neologismo "complejado" por el término "combinado" que sería mucho mas correcto.

El problema de los barbarismos es que a veces acaban siendo aceptados ya que su uso se generaliza por personas cultas e incluso por escritores de renombre. Precisamente este número monográfico de Archivos Españoles de Urología sobre cáncer de próstata esta escrito por algunos de los mejores equipos urológicos de España y Europa con lo que los conceptos por ellos expresados y, por ende, los términos que utilizan serán asimilados por el resto de profesionales de este campo con lo que al final muchos acabaran empleando como correcto este innecesario barbarismo.

Dr. Alejandro Sousa Escandón Urólogo. Hospital Comarcal de Monforte. 